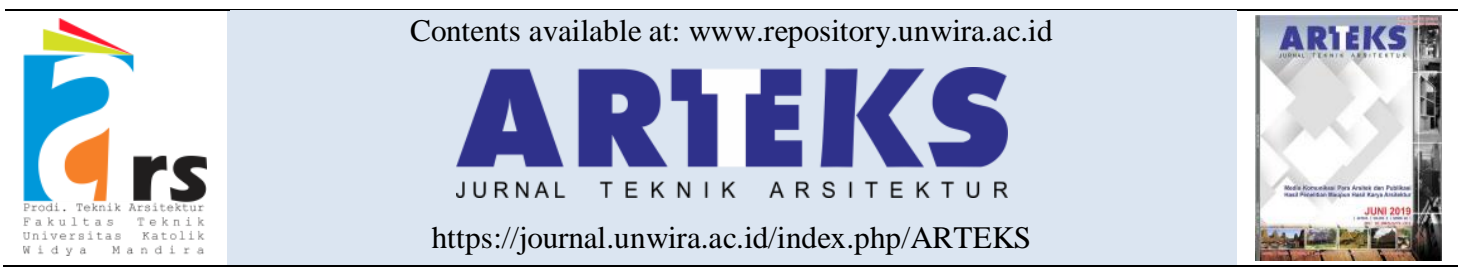

Research paper

doi: 10.30822/arteks.v5i3.504

\title{
The role of space in sustaining children's traditional games
}

\author{
Dhini Dewiyanti Tantarto ${ }^{1 * \mathbb{D}}$, Dianna Astrid Hertoery ${ }^{2}$ \\ ${ }^{1}$ Architecture Engineering Study Program, Faculty of Engineering and Computer Science \\ (FTIK), Universitas Komputer Indonesia (UNIKOM) \\ Jl. Dipati Ukur 112-119, Bandung - 40132, Indonesia \\ ${ }^{2}$ Architecture Engineering Study Program, Faculty of Civil Engineering and Planning \\ (FTSP), Universitas Kebangsaan (UKRI) \\ Jl. Terusan Halimun 37, Bandung - 40263, Indonesia
}

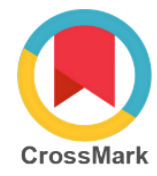

\begin{tabular}{l}
\hline ARTICLE INFO \\
\hline Article history: \\
Received May 12, 2020 \\
Received in revised form May 30, 2020 \\
Accepted July 27, 2020 \\
Available online December 01, 2020
\end{tabular}

\section{Keywords: \\ Space character \\ Space of children's \\ Space requirements \\ The role of space \\ Traditional games}

*Corresponding author: Dhini Dewiyanti Tantarto

Architecture Engineering Study Program,

Faculty of Engineering and Computer

Science, Universitas Komputer Indonesia

Email: dhini.dewiyanti@email.unikom.ac.id

ORCID: https://orcid.org/0000-0002-8993-

7929

\section{ABSTRACT}

Playing is one of the activities naturally possessed by children from childhood and elements of learning have been observed to be in playing and vice versa. For example, traditional games have philosophical values with moral messages but they have been replaced by games prioritizing technological advancements over time. This has reduced the familiarity of many children with traditional games in recent times. Meanwhile, the reduction in the quantity and quality of play and public open space for children is often considered one of the factors causing the extinction of traditional games. The availability of an adequate environment including play areas or playground aids children's development. This paper discusses the traditional games known by the present generation and the role of space in sustaining them with the focus on West Java. The study was conducted through observation and distribution of questionnaires to children aged 6-12 years living in Bandung city and some urban settlements. The results provided an overview of the types of traditional games known by the children, the space they favored, and its role in their willingness to play.

\section{Introduction}

Childhood is an important period in a child's development due to the participation in several play activities (Piaget and Cook 1952; Piaget 2013a; 2013b). This means it is not possible to separate children and play (Burke 2005). It has also been discovered there are elements of learning in these activities and play is also sometimes spontaneously inserted in the learning process with a variety of creativity to ease boredom (Gallahue and Cleland-Donnelly 2007; Lafferty 2005). The activities help children achieve gradual and complete development physically, intellectually, socially, morally, and emotionally (Goodway, Ozmun, and Gallahue 2019; Barnett 1990; Hughes 2009).

The traditional game is owned by almost all people in different parts of the world with different names often given to similar games. They are mostly hereditary and transferred from previous generations with their inherent cultural and philosophical values (Shinta, Syamsi, and Haryanto 2019). Through playing, children are taught to foster the value of competitiveness, the spirit of togetherness, help, tolerance, 
sportsmanship, the spirit of building, as well as the love of nature and living things (Solnit 1998; Kuczyński 1984; Klein 1929; Chudacoff 2008). Subsequently, the games also train motor skills due to the presence of elements of motion, running, jumping, crouching, tiptoeing, kneeling. It teaches counting, frugality, and strategy and develops children's creativity, especially during the process of selecting appropriate playing materials such as stones/gravel, banana fronds, leaves, trees, and others. The games have a high value of flexibility due to the possibility of engaging in them individually or in groups, indoor or open space. There, several positive values are obtained from these traditional games.

Children basically need a positive environment in the form of play space to facilitate positive activities to aid their development (Dewiyanti 2011). This is associated with the ability of a good space for play to affect the quality of play as well as their psychological and motor development (Senda 1992; Senda et al. 1998).

The less participation in traditional games in recent times has, therefore, been linked to the reduction in playgrounds, urban public spaces, and natural physical environment due to the development and the rapid advancement in technology. Moreover, the recent generation of children prefers technology-based games such as androids, gadgets, and play stations which can be played personally, anytime, and anywhere without the need for any special space.

The purpose of this research is to explore the in-depth knowledge of the recent generation of children about traditional games, the kinds they play, and the architectural role of space in ensuring their continuity. It is, therefore, important to conduct this study in order to preserve traditional games with positive values and also to determine the role of architecture in providing good space for its sustenance and participation of children. Similar research was conducted by Gelisli and Yazici (2015) with the focus on children's traditional games in the Konya region and Turkey (Gelisli and Yazici 2015). Roscoe (2018) also researched 2000 parents in the United Kingdom and almost $100 \%$ reported the importance of traditional games recognition and introduction due to their several benefits in the development of a child's personality (Roscoe 2018). They were also found to be suitable for the development of a child's age.
This study was conducted by observing several children aged 6-12 years living in Bandung city and some urban settlements. This age group was selected due to their ability to communicate and express opinions both orally and written (Papalia, Olds, and Feldman 2005). The analysis showed the types of traditional games they recognize, types of games they play, and the spaces they love when playing games. The results are expected to be useful as a basis for major research in mapping the traditional games for Indonesian children in the sustainability concept.

\section{Method}

The study started through the distribution of questionnaires to children aged 6-12 years, living in Bandung, and urban or planned settlements around the Antapani as well as urban villages or unplanned settlements located in the Lingga Wastu area directly bordering the Cikapundung River. The study areas were observed to have the same conditions including a school, a fairly large river, varieties of environmental nuances between the artificial environment, and trees with each of them recording 50 children going to school. These areas were considered based on the elementary school age range, the strong influence of environment on children's development, and the increasing desire to explore and seek adventure (Waite, Rogers, and Evans 2013; Dewiyanti 2011; Owens 1992). Outdoor spaces in the form of parks or shared spaces, rivers, suitable environmental roads, and free yards considered to be healthy were found in the selected locations. Meanwhile, a natural environment, garden, or shared space is believed to have the power to attract children to play games and ultimately interact with each other.

The research questions provided include (1) what kind of traditional games do children know? and (2) Do children still play such traditional games and where? These questions were asked to determine the character of the games and the kind of space that stimulates them or vice versa.

The next question was "does space trigger certain types of games or is there no relationship between them?" It is important to confirm this in order to confirm or refute the assumption that the reduction in outside urban space reduces play areas for children. According to Wonoseputro 
(2007), the non-involvement of children in the arrangement of urban public space areas makes them lose their proper playground and this usually leads to the development of invisible playgrounds (Wonoseputro 2007; Liem and Lake 2018).

The children found to be engaging in the traditional games were interviewed and asked to show the location being referred. Some were also invited to express their preferred space for playing activities and the information retrieved from these verbal/oral expressions were analyzed using content analysis methods to determine, group, and interpret the frequently used important words (Franzosi 2004).

\section{Result and discussion}

\section{Classification of traditional games in West Java}

Some traditional games in West Java are classified based on the space used either inside or outside, social interaction either individual or group, tools, and gender groups as shown in table 1 .

Table 1. Traditional game groups

\begin{tabular}{|c|c|c|c|c|c|c|c|c|}
\hline \multirow[t]{2}{*}{$\begin{array}{l}\text { The name of the } \\
\text { game }\end{array}$} & \multicolumn{2}{|c|}{ हึ } & \multicolumn{2}{|c|}{ 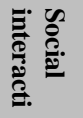 } & \multicolumn{2}{|c|}{$\overrightarrow{8}$} & \multicolumn{2}{|c|}{ อิ } \\
\hline & 1 & 2 & 3 & 4 & 5 & 6 & 7 & 8 \\
\hline Bebentengan & & $\sqrt{ }$ & & $\sqrt{ }$ & & $\sqrt{ }$ & $\sqrt{ }$ & \\
\hline $\begin{array}{l}\text { Congklak (mancala } \\
\text { games) }\end{array}$ & $\sqrt{ }$ & & & $\sqrt{ }$ & $\sqrt{ }$ & & & $\sqrt{ }$ \\
\hline Egrang (stilts) & & $\sqrt{ }$ & $\sqrt{ }$ & & $\sqrt{ }$ & & $\sqrt{ }$ & \\
\hline Gangsing/gasing & $\sqrt{ }$ & $\sqrt{ }$ & $\sqrt{ }$ & $\sqrt{ }$ & $\sqrt{ }$ & & $\sqrt{ }$ & \\
\hline Gatrik & & $\sqrt{ }$ & & $\sqrt{ }$ & $\sqrt{ }$ & & $\sqrt{ }$ & \\
\hline Gobag sodor & & $\sqrt{ }$ & & $\sqrt{ }$ & & $\sqrt{ }$ & $\sqrt{ }$ & $\sqrt{ }$ \\
\hline Kelereng (marbles) & & $\sqrt{ }$ & & $\sqrt{ }$ & $\sqrt{ }$ & & $\sqrt{ }$ & \\
\hline Ketapel (catapult) & & $\sqrt{ }$ & $\sqrt{ }$ & & $\sqrt{ }$ & & $\sqrt{ }$ & \\
\hline Engkle (hopscotch) & & $\sqrt{ }$ & & $\sqrt{ }$ & & $\sqrt{ }$ & & $\sqrt{ }$ \\
\hline $\begin{array}{l}\text { Petak umpet/ucing } \\
\text { sumput (hide and } \\
\text { seek) }\end{array}$ & $\sqrt{ }$ & $\sqrt{ }$ & & $\sqrt{ }$ & & $\sqrt{ }$ & $\sqrt{ }$ & $\sqrt{ }$ \\
\hline Oray-orayan & & $\sqrt{ }$ & & $\sqrt{ }$ & & $\sqrt{ }$ & $\sqrt{ }$ & $\sqrt{ }$ \\
\hline Endog-endogan & & $\sqrt{ }$ & & $\sqrt{ }$ & & $\sqrt{ }$ & $\sqrt{ }$ & $\sqrt{ }$ \\
\hline
\end{tabular}

\begin{tabular}{|c|c|c|c|c|c|c|c|c|}
\hline \multirow[t]{2}{*}{$\begin{array}{l}\text { The name of the } \\
\text { game }\end{array}$} & \multicolumn{2}{|c|}{ है } & \multicolumn{2}{|c|}{ 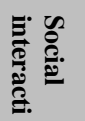 } & \multicolumn{2}{|c|}{$\frac{\overrightarrow{8}}{\infty}$} & \multicolumn{2}{|c|}{ อ̊ } \\
\hline & 1 & 2 & 3 & 4 & 5 & 6 & 7 & 8 \\
\hline $\begin{array}{l}\text { High jump rubber } \\
\text { game }\end{array}$ & $\sqrt{ }$ & $\sqrt{ }$ & & $\sqrt{ }$ & $\sqrt{ }$ & & & $\sqrt{ }$ \\
\hline $\begin{array}{l}\text { Sapintrong rubber } \\
\text { band }\end{array}$ & $\sqrt{ }$ & & & $\sqrt{ }$ & $\sqrt{ }$ & & & $\sqrt{ }$ \\
\hline Alung sarung & & $\sqrt{ }$ & $\sqrt{ }$ & & $\sqrt{ }$ & & $\sqrt{ }$ & \\
\hline Galah bandung & & $\sqrt{ }$ & & $\sqrt{ }$ & & $\sqrt{ }$ & $\sqrt{ }$ & $\sqrt{ }$ \\
\hline Hahayaman & & $\sqrt{ }$ & & $\sqrt{ }$ & & $\sqrt{ }$ & $\sqrt{ }$ & $\sqrt{ }$ \\
\hline $\begin{array}{l}\text { Beklen } \\
\text { (knucklebones) }\end{array}$ & $\sqrt{ }$ & & & $\sqrt{ }$ & $\sqrt{ }$ & & & $\sqrt{ }$ \\
\hline \multicolumn{9}{|l|}{ Note: } \\
\hline 1: Indoor & \multicolumn{8}{|c|}{ 5: Need a tool } \\
\hline 2: Outdoor & \multicolumn{8}{|c|}{ 6: Does not need a tool } \\
\hline 3: Individual & \multicolumn{8}{|c|}{ 7: Commonly played by male } \\
\hline 4: Group & \multicolumn{8}{|c|}{ 8: Commonly played by female } \\
\hline
\end{tabular}

Three categories of these games were identified and they include those (1) still known and played by the children with the meaning understood; (2) played by children without knowing it is a traditional game; and (3) totally unknown by the children as shown in figures 1 and figure 2 .

Figure 1 shows the games in planned settlements while figure 2 indicates those in unplanned ones. The term planned settlements used in this paper include the areas spatial arranged based on the theoretical rules applied by both government and private developers. They already have complete and standard facilities such as schools, playgrounds, public spaces, and roads.

Meanwhile, unplanned settlements are naturally developed areas based on the needs of the settlers without any reference to the theoretical rules of the existing spatial order (Purbadi, Djunaedi, and Sudaryono 2019; Refranisa 2019; Mahagarmitha 2018; Bawole 2020). They are usually characterized by dense settlements and inhabited by middle to lowerincome people for generations. Furthermore, spatial planning is usually an agreement made among the residents (Kustianingrum 2010). This, however, does not mean unplanned settlements always grow into slum areas. 


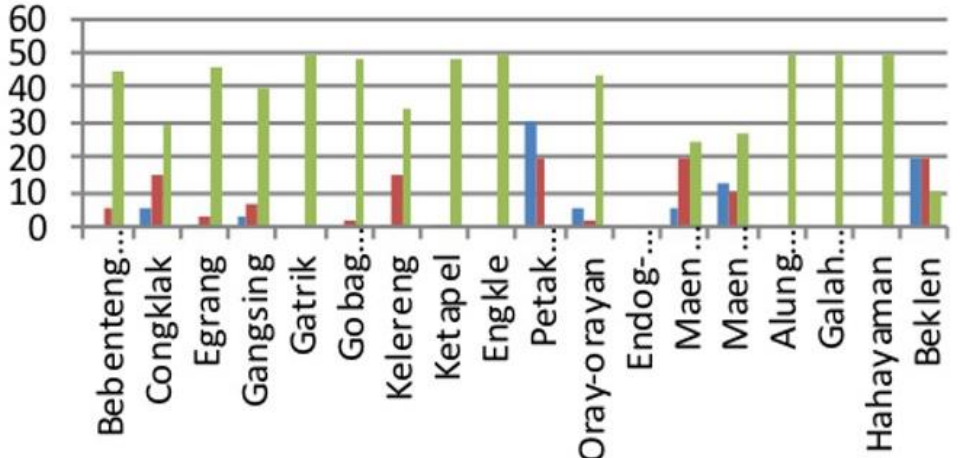

Figure 1. Games in planned settlement areas
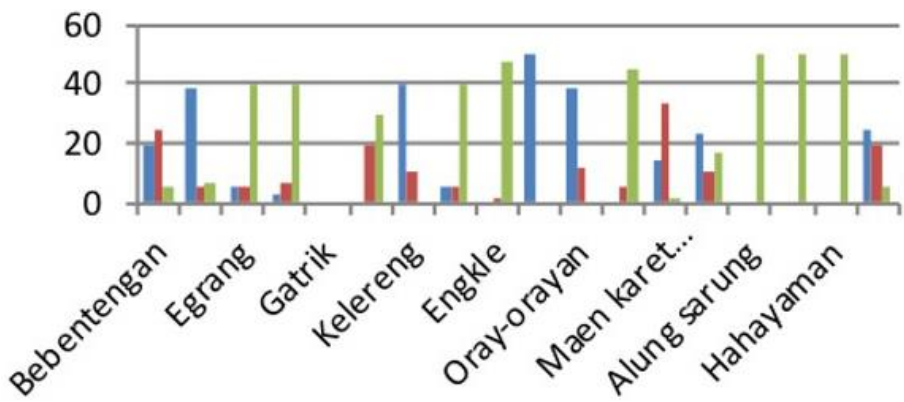

know the game and understand its meaning

do the game, but don't know that the game is a traditional type of game

Figure 2. Games in unplanned settlement areas

Several traditional games from West Java are unknown and almost disappearing such as pérépét jengkol, sorodot gaplok, paciwit-ciwit lutung, ningnang, ucing kuriling, tokecang, pepeletokan, encrak, sermén, sutén, sasalimpetan, pélak cau, ole-ole ogong, meuncit reungit, jajangkungan, ngajajar tilu/jarlu, gugunungan, ayang - ayang gung, maén bandring and maén panggal, bolu bogem, ambil-ambilan, ucing pengpeun, cingcangkeling, gegelebusan, ucing pegat, galah bandung, galah burulu, and others.

Most of these unknown games are generally a combination of Sundanese sound art, for example, ole-ole ogong which is a children's game usually played in the rice harvest season. It involves the children walking hand in hand along the edge of the paddy field, blowing trumpets made from dry straw, and singing "olé-olé ogong, melak cabe di tarogong, dihakanku embe ompong, diteang kari sapotong". Meanwhile, the pérépét jengkol game requires the cooperation of several people as shown in figure 3 . It gives the children joy when they accompany their parents at the village in welcoming the rice harvest season.

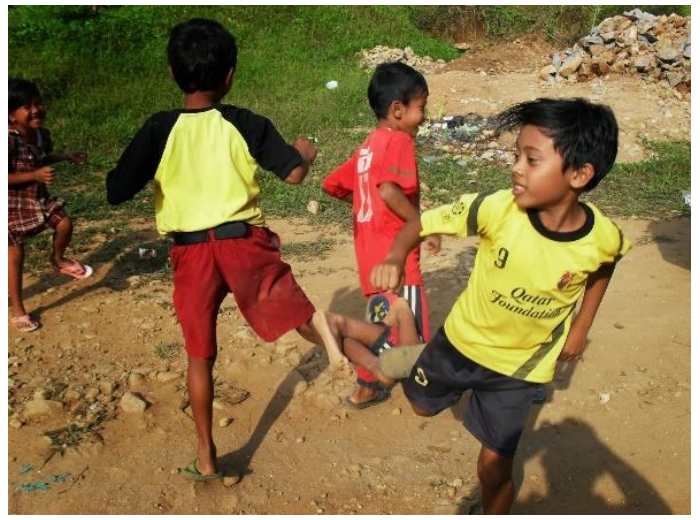

Figure 3. Pérépét jengkol

Source: (Sunarya 2013)

The traditional games known by the children and their favorite space

From the many types of traditional games found in the study area, apparently, only a few are still being played with some generally observed to be conducted in certain spaces. The observations and interviews with the children showed they prefer open space, both planned and spontaneous, to closed space as shown in table 2. The spontaneity is attached to the fact that children play reflexively, especially when walking with their friends, for example, from school to their 
homes. This is possible because the schools are located in settlements areas and this requires the children trek to and fro.

Table 2 shows closed space does not stimulate children to play traditional games. This is understandable because it currently offers thematic games such as dexterity machines and several others and this reduces the relationship with their peers.

Table 2. Space for play

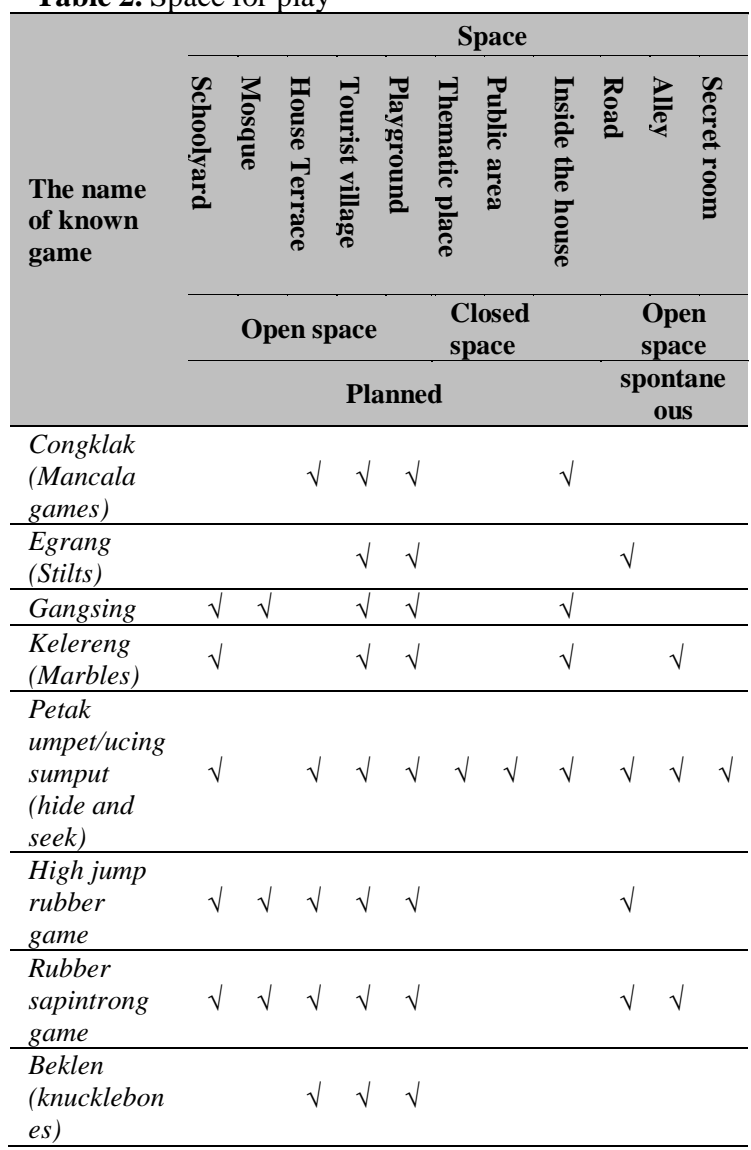

Figure 4 shows how open space is favored by children as a place stimulating to them to participate in traditional play activities, mainly because it allows free movement, especially in an area dominated more by an empty space. This is in line with the findings of Casey (2007) that open space offers free movement, activity choices, and flexibility for children to move as they wish without fear of damage (Casey 2007). In an uninhibited space, children are usually segregated by age group and type of play. Moreover, some games are not affected by gender even though some shows the tendency for gender-based specialization such as marbles. A stimulated open space with special features such as trees, poles, tubs, chairs, and others can also be used as a game aid. According to Harten, Olds, and Dollman (2008), varieties of features in space allow children to creatively select play aids out of different choices (Harten, Olds, and Dollman 2008).

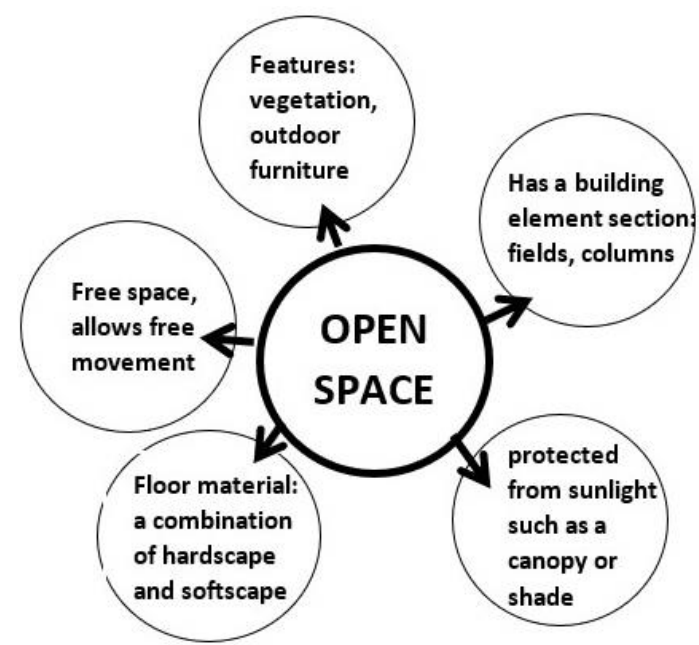

Figure 4. The characteristics of open space with the ability to stimulate games

\section{Through pictures, children argue}

Children were able to discuss using picture expressions of they expect in a good schoolyard as shown in figure 5. Some of the features such as trees, benches, game furniture, and even trash cans are things observed to have the ability to improve children's creativity while playing as reflected in their drawings.

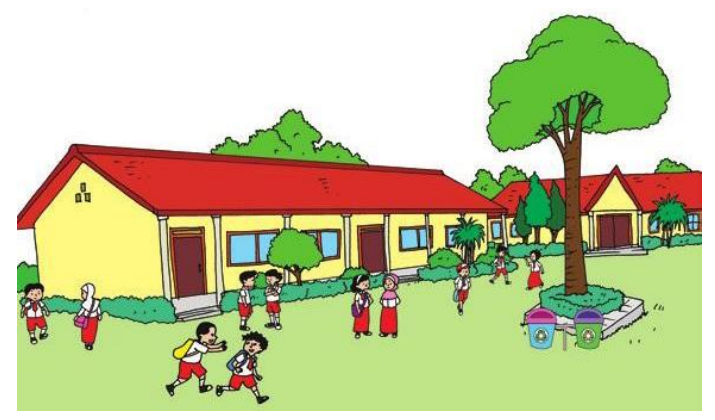



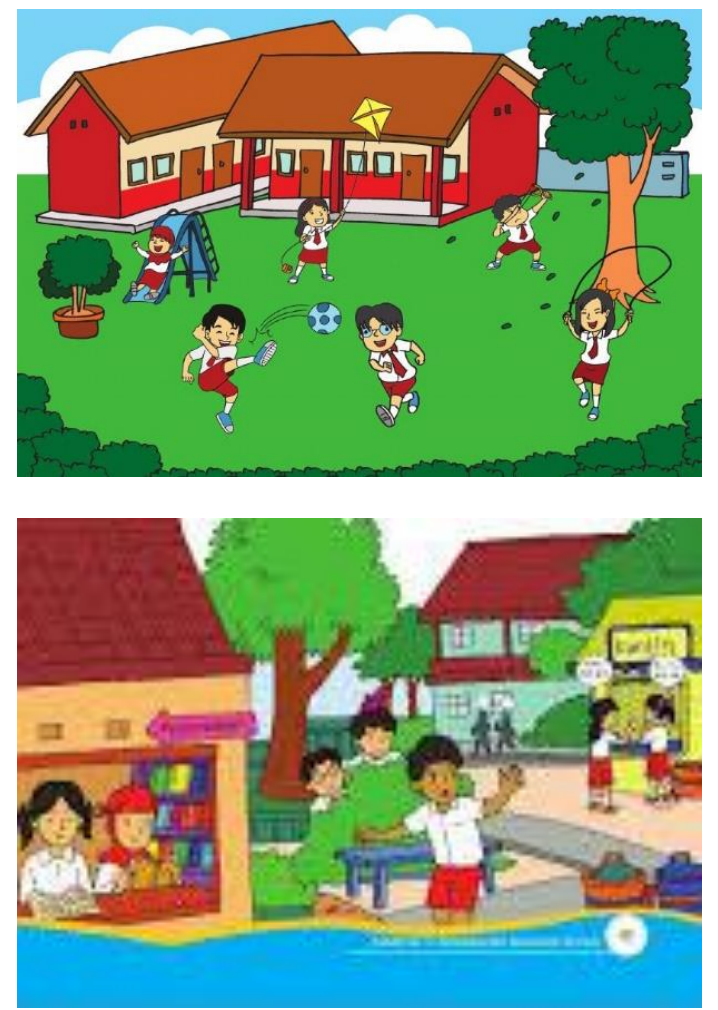

Figure 5. Characteristics of children's school yards

According to Bland (2012), children's drawings are actually an imagination of their wishes and the images shown indicate the children expect a school environment with several building elements and apparently without luxury material (Bland 2012). The green aspects of the drawings in the also mean they crave a beautiful school to support their playing activities.

Broda (2007) showed there is no ideal standard for children's playgrounds because they have their instincts in choosing where to play (Broda 2007). However, it is better if adults are able to provide diverse landscape features, for example, through gentle contours, vegetation as well as soft and hard play materials on the land to stimulate them.

Rogers (1976) examined the influence of the school's spatial organization in shaping children's behavior and its effects on their creativity and emotional level (Rogers 1976). Francis (1988) also showed the importance of accepting children's aspirations and negotiating with parents when planning a playing environment or a school environment to ensure it accommodates children's positive play needs (Francis 1988). Broda (2007), however, concluded that the schoolyard is the best play facility for a child's development, therefore, it is important for parents to choose a school with a well-planned yard facility as well as maintain a balance between academic and play needs (Broda 2007).

\section{Road as a magnet for children}

The road was found in both planned and unplanned settlements to have a special attraction for children to play. This is associated with the fact they attend school in the environment and this allows them to play on the road while going to school and coming back home. This usually happens spontaneously.

Karsten and Van Vliet (2006) and Tranter and Doyle (1996) showed urban children are indeed accustomed to "reconciling" with motorized vehicles to play on residential streets or alleys (Karsten and Van Vliet 2006; Tranter and Doyle 1996). Even though it is dangerous, road space is able to provide creativity that stimulates the desire to play. Figure 6, however, shows the danger with the spontaneous playing activities of children on the road.

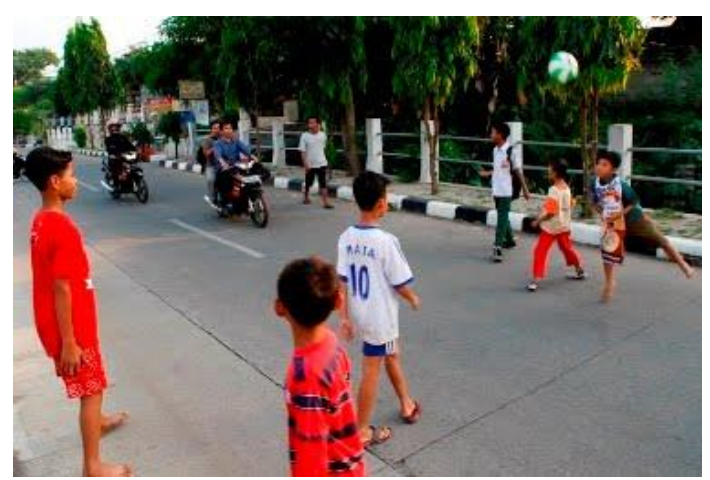

Figure 6. Playing on a dangerous road

There is a need for agreements between settlement managers, residents, and parents to implement positive playing activities on the road. An example of this shown in figure 7 with the schools and community discovered to be teaching and introducing the children to traditional games by playing on the road. The play zone can, however, be provided by the parents or the children themselves as shown in the following pictures. 

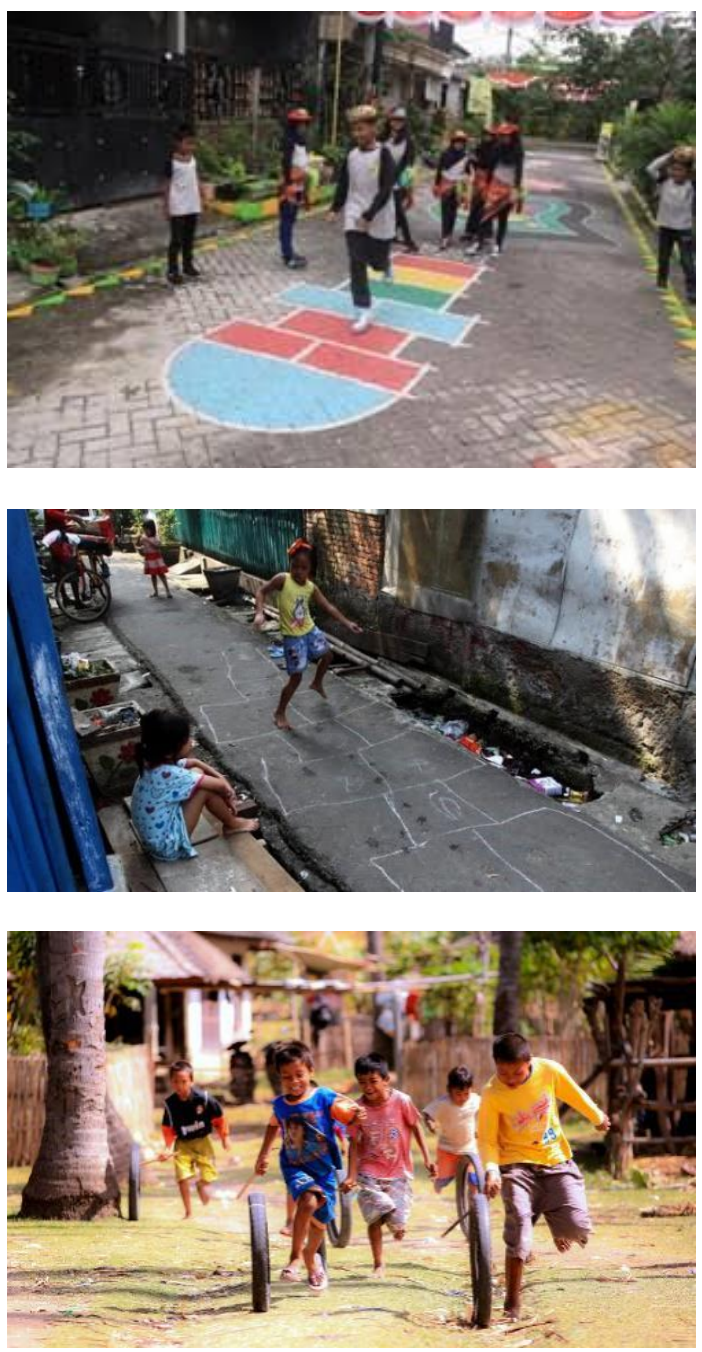

Figure 7. Playing traditional games on the road Source: (Riyadi 2020)

In unplanned settlements, children were observed to be playing on the road while begging and this is associated with the fact that the area is inhabited by people with non-permanent income. Therefore, the children help their parents by begging or selling on the street and also playing in the process.

The role of adults in introducing traditional games

It is impossible for children to know traditional games without the intervention of adults at home and at school. Therefore, these games can only be sustained through the participation of both the children and their parents. According to Ginsburg (2007), adult involvement has the ability to strengthen emotional bonds between children and parents as well as their teachers (Ginsburg 2007). Another research has shown that playing together, teaching, or just watching children play makes them feel the love of parents and create a sense of security in them (Yudiwinata 2014).

Roopnarine (2011) also showed it is important for parents to introduce several cultures to their children starting from childhood to help them develop tolerance, insight, and empathy to enrich their cognitive aspects (Roopnarine 2011). These cultures certainly include traditional games which are not only to teach the children how to play but also the philosophy of the game. Figure 8, however, shows the teacher's involvement in participating and introducing traditional games to children.
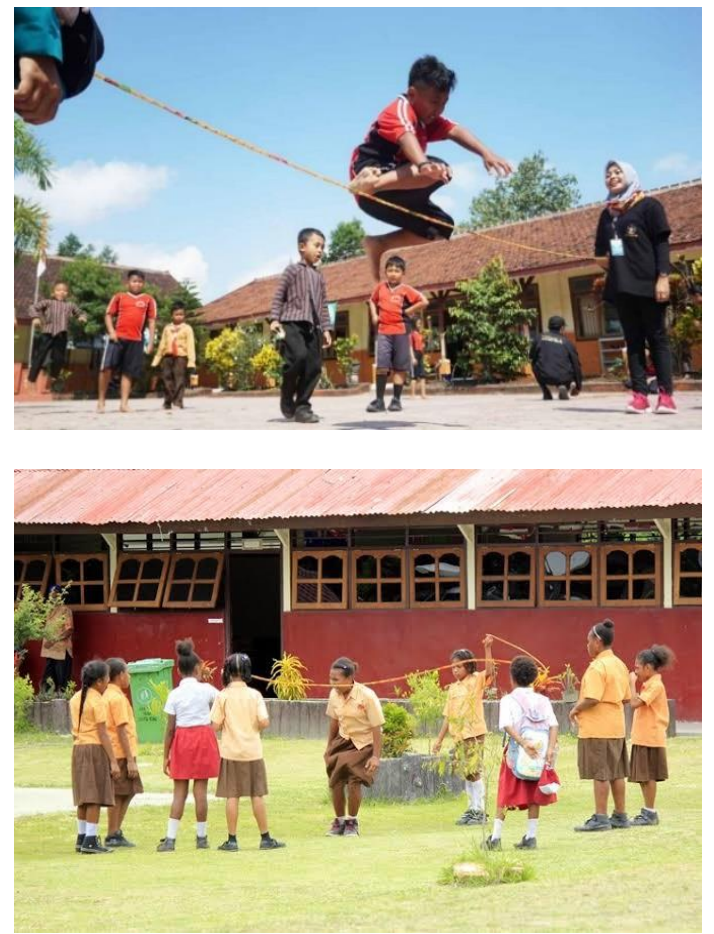

Figure 8. Traditional game with adult guides

\section{Tools and playing time}

The tools for traditional games are very easy such that children have the ability to produce themselves or buy in stores selling the equipment. These games are better compared to modern ones based on the togetherness and cooperation established among the children and this further makes the tools cheaper and easy to obtain (Kurniati 2016; Nur 2013). Figure 9, therefore, shows some of the play media and tools that can be bought or made by the children. 

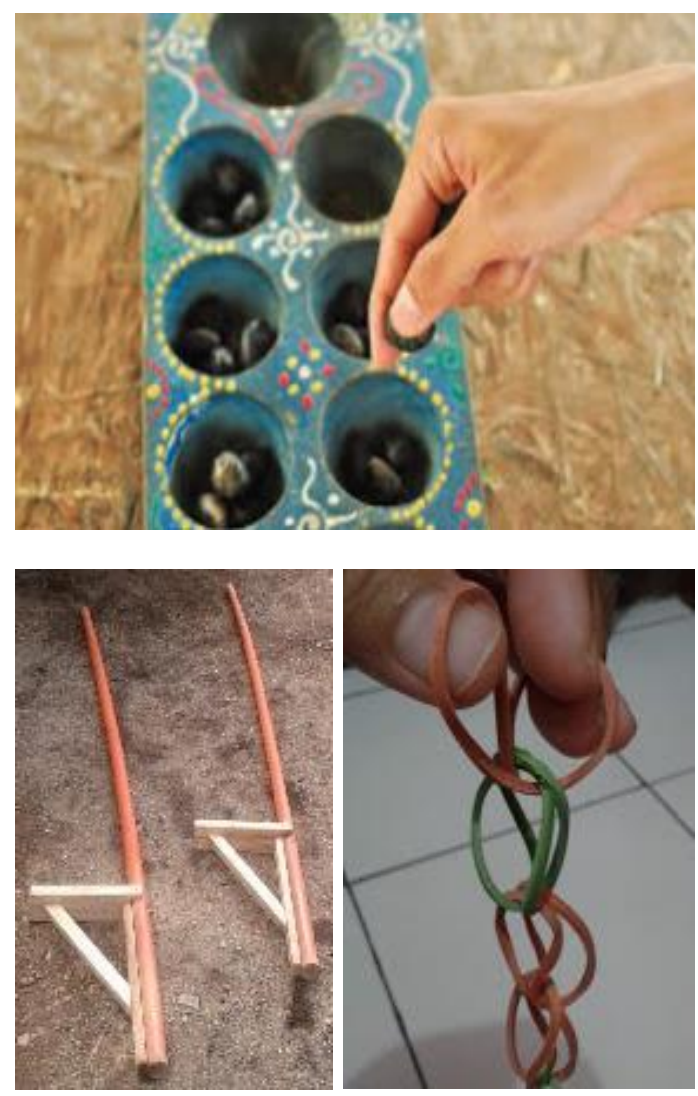

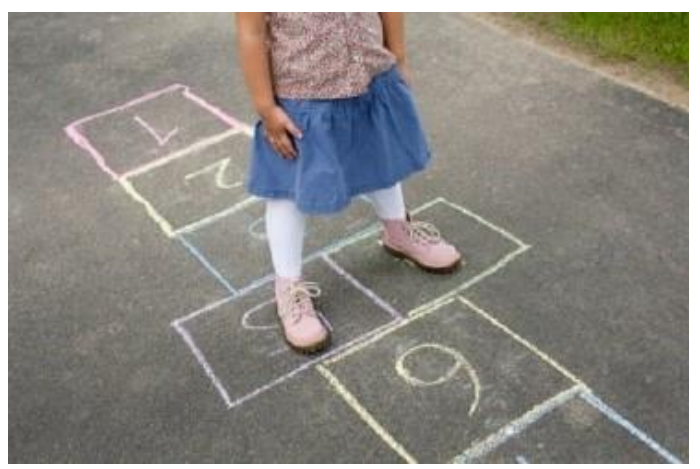

Figure 9. Traditioanl game tools Source: (Silaen 2017)

The observations and interviews with the children in the study areas showed the material used, method of obtaining play material, and the preferred time of playing as shown in table 3 . Generally, it is easy for children to make and produce tools or playing materials because they are provided by nature. Some of these include stones/gravel, trees/vegetation, banana fronds, shells or tree seeds, twisted rubber, bamboo, grapefruit skin, and others. Moreover, the search for these materials stimulates children's creativity and aid their cognition.

These games are generally played during school holidays and certain celebratory moments such as Scout Day, Independence Day, Kartini day, and several others. They are usually designed by the school and this shows the importance of school in ensuring their survival and preservation.

Table 3. Material, method, and time

\begin{tabular}{llll}
\hline Game & Material & How to get material & Time \\
\hline $\begin{array}{l}\text { Congklak (mancala } \\
\text { games) }\end{array}$ & $\begin{array}{l}\text { Plastic, wood, remaining } \\
\text { shells, seeds obtained from } \\
\text { the road or garden, gravel }\end{array}$ & $\begin{array}{l}\text { Shop, pick up from the beach, } \\
\text { pick up on the street }\end{array}$ & $\begin{array}{l}\text { During holidays or } \\
\text { celebratory moments }\end{array}$ \\
\hline Egrang (stilts) & Wood, bamboo & $\begin{array}{l}\text { Made by parents or adults, self- } \\
\text { made }\end{array}$ & $\begin{array}{l}\text { During holidays or } \\
\text { celebratory moments }\end{array}$ \\
\hline Gangsing & Plastic, wood & Buy & During the holidays \\
\hline $\begin{array}{l}\text { Kelereng (marbles) } \\
\text { sumput (hide and seek) }\end{array}$ & Glass marbles & $\begin{array}{l}\text { Buy } \\
\text { buckets, beds, and so on }\end{array}$ & $\begin{array}{l}\text { When vacation, after } \\
\text { school }\end{array}$ \\
\hline High jump rubber game & $\begin{array}{l}\text { Rubber, plastic } \\
\text { environment }\end{array}$ & $\begin{array}{l}\text { When on vacation, } \\
\text { after school, when } \\
\text { together with friends }\end{array}$ \\
\hline Rubber sapintrong game & $\begin{array}{l}\text { Rubber, plastic } \\
\text { Beklen (knucklebones) }\end{array}$ & $\begin{array}{l}\text { Plastic balls, golf balls, } \\
\text { rubber balls, knucklebones, } \\
\text { shells }\end{array}$ & $\begin{array}{l}\text { Buy, self-made. } \\
\text { celebratory moments }\end{array}$ \\
\hline
\end{tabular}




\section{Petak umpet/ucing sumput as a sustainable game}

The information obtained from the children showed petak umpet/ucing sumput or hide and seek is the most well-known game up to date even in various parts of the world (Barritt et al. 1944). According to Peskin and Ardino (2003), this game is able to train children to keep secrets and practice patience (Peskin and Ardino 2003). Moreover, children learn the game first from their mothers, doubling as their first teacher, especially when they are being taught about the space in the house.

The game is popular because it is (1) cheap, (2) easy, (3) can be conducted anytime and anywhere, and available, (4) for all ages, genders, groups, and even races throughout the world. It has the ability to establish communication without the use of spoken words and this makes it sustainable. The game also requires the children to think fast in exploring the spaces available in the environment to hide as shown in figure 10. Sometimes the element of togetherness and teasing colleagues in charge of searching becomes more dominant when children run out of ideas in finding space.
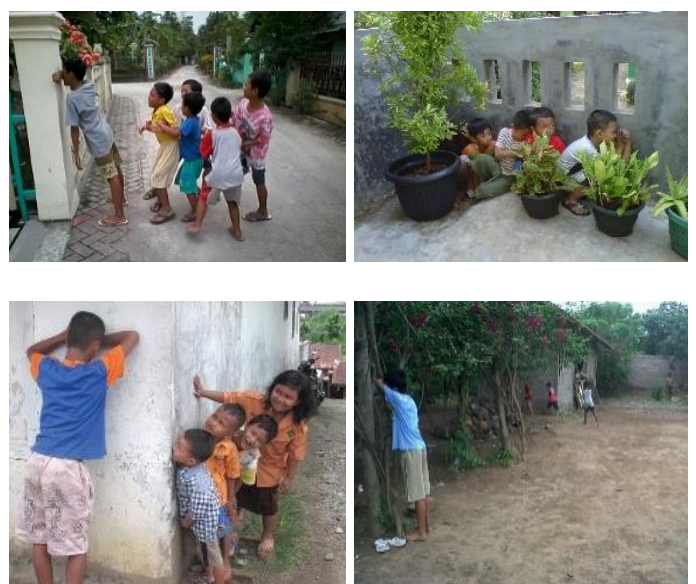

Figure 10. Playing hide and seek (Petak umpet) with friends

\section{The space with the ability to stimulate traditional game activities}

It is important to preserve traditional games due to the several positive benefits it presents to the children's growth as shown in figure 11.

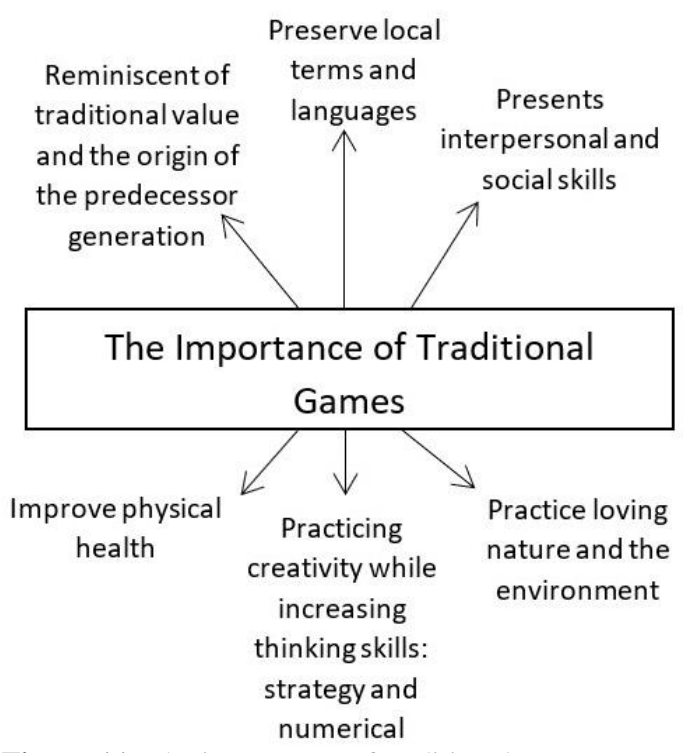

Figure 11. The importance of traditional games

A space for play is required to implement these traditional game activities but the quality of public open spaces in urban areas has been discovered not to fulfill the criteria required to stimulate the children. This is because they are more dominated by city parks filled with ornamental plants with insufficient free space for movement, jumping, squatting, and rolling for both individuals and groups.

Children are more stimulated to engage in traditional game activities by free space for movement both indoors and outdoors planned based on design rules or due to spontaneous actions. It is, however, possible to equip the spaces with natural and artificial features to aid the children's activities. These include a composition of hard or hardscape and soft or softscape materials with the assurance they have the ability to ensure safety and comfort, considering the fact that children are very careless and tend to ignore safety factors. This type of space is further explained in the following figure 12. 


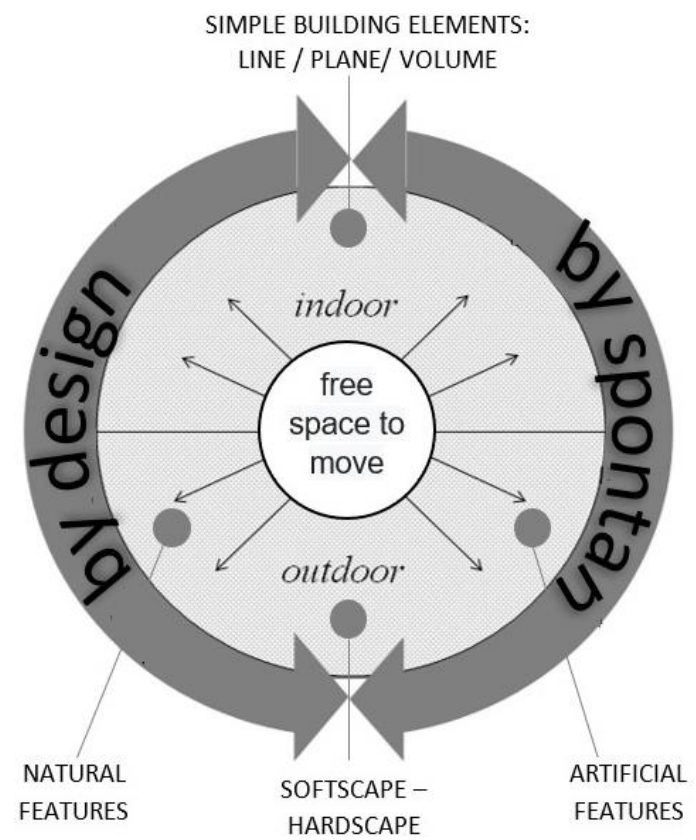

Figure 12. Space with the ability to simulate traditional games

This is in line with Senda's (1998) general classification of children's play environment into 6 spatial categories including (1) natural with several elements such as trees and rivers; (2) open space; (3) road; (4) anarchy or unplanned space appearing according to the child's imagination, and usually in the form of "tough" games such as chasing and fighting; (5) secret hiding rooms with the spaces known only to certain groups of children; and (6) planned space for play. Meanwhile, parents are required to first facilitate a traditional space for play (Senda et al. 1998).

\section{Space for play as a trigger for traditional games}

Certain spaces were found to have the ability to trigger children's desire to play traditional games and this is usually strengthened by the presence of an "opponent player" or a friend at an appropriate time or moment. Therefore, the spaces with the suitable game based on their features include:

1. Open space with natural and artificial features: hide and seek games.

2. Open spaces and aisles with flat floors: marbles and jumping rope.

3. Space in the form of a hallway: knucklebones, congklak, and jump rope.

4. Open spaces, especially with soft stretches: stilts.

\section{Conclusion}

Several conclusions were obtained from the data analysis and some of the traditional games observed to be relevant in the studied are congklak (mancala games), stilts (egrang), trim (gangsing), marbles, petak umpet/ucing sumput (hide and seek), high rubber jump (high jump using rubber bands), sapintrong rubber band, and knucklebones. These games are usually played with peers during school holidays and certain celebratory times. However, some of those not known by the children include pérépét jengkol, sorodot gaplok, paciwit-ciwit lutung, ningnang, ucing kuriling, tokecang, pepeletokan, encrak, sermén, sutén, sasalimpetan, pélak cau, ole-ole ogong, meuncit reungit, jajangkungan, ngajajar tilu/jarlu, gugunungan, ayang - ayang gung, maén bandring and maén panggal, bolu bogem, ambil-ambilan, ucing pengpeun, cingcangkeling, gegelebusan, ucing pegat, galah bandung, galah burulu, and others. They were discovered not to be known by the children because they are not introduced to them and they generally require dance moves and sound art.

Some other games are being played by children with the help of those concerned with the existence of traditional games. In this case, the teachers, parents, and the community are very influential in ensuring the sustenance of the games. It was also discovered that they are mostly played in structured spaces such as schools or thematic villages deliberately built to educate children or introduce them to the natural life of the village. Moreover, the sustainability of the games is supported by the modification of toy materials and play systems.

Open spaces, roads, and spaces intended for children to play also have a significant role and this means they need to be highly prioritized by the planners. Meanwhile, these spaces and playgrounds would be meaningless without the parents, teachers, and observers introducing the games. This, therefore, places the space in the second layer after the knowledge and experience of parents are transmitted to children as indicated in figure 13. The transmission makes them understand the traditional game philosophy and a positive play experience thereby stimulating their desire to play in the space. 


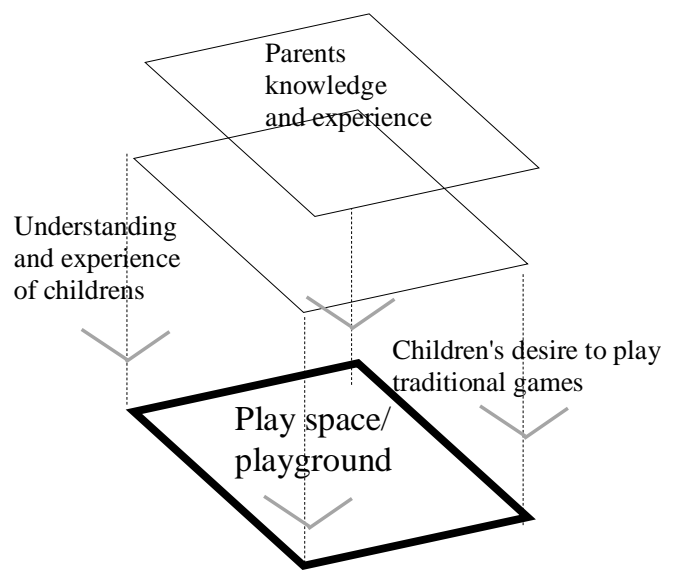

Figure 13. The role of space as the second layer

This research showed the traditional games not recognized and played by the children and the sustenance of these games is expected to be a matter of concern for all due to its noble value in building positive child character.

\section{Acknowledgment}

The author sincerely appreciates the 5th-grade students of Antapani and Linggawastu elementary schools for being the resource persons for this article.

\section{References}

Barnett, Lynn A. 1990. 'Developmental Benefits of Play for Children'. Journal of Leisure Research $22 \quad$ (2): 138-53. https://doi.org/10.1080/00222216.1990.1196 9821.

Barritt, Loren, Ton Beekman, Hans Bleeker Bleeker, and Karel Mulderij. 1944. 'The World Through Children's Eyes: Hide and Seek \&amp; Peekaboo'. Phenomenology + Pedagogy, December, 140-61. https://doi.org/10.29173/pandp14875.

Bawole, Paulus. 2020. 'The Development of Urban Kampong as One the Alternatives Special Interest Tourism'. ARTEKS: Jurnal Teknik Arsitektur 5 (1): 115-26. https://doi.org/10.30822/arteks.v5i1.362.

Bland, Derek. 2012. 'Analysing Children's Drawings: Applied Imagination'. International Journal of Research \& Method in Education 35 (3): 235-42.
https://doi.org/10.1080/1743727X.2012.7174 32.

Broda, Herbert W. 2007. Schoolyard-Enhanced Learning: Using the Outdoors as an Instructional Tool, K-8. Portland, Maine, United States: Stenhouse Publishers.

Burke, Catherine. 2005. "Play in Focus": Children Researching Their Own Spaces and Places for Play'. Children, Youth and Environments $\quad 15 \quad$ (1): 27-53. https://www.jstor.org/stable/10.7721/chilyout envi.15.1.0027.

Casey, Theresa. 2007. Environments for Outdoor Play: A Practical Guide to Making Space for Children. 1 Oliver's Yard, 55 City Road, London EC1Y 1SP United Kingdom: SAGE Publications Ltd. https://doi.org/10.4135/9781446214206.

Chudacoff, Howard P. 2008. Children at Play: An American History. New York: NYU Press.

Dewiyanti, Dhini. 2011. 'Ruang Terbuka Hijau Kota Bandung'. Jurnal Majalah Ilmiah Unikom 7 (1). https://jurnal.unikom.ac.id/jurnal/ruangterbuka-hijau-kota.n.

Francis, Mark. 1988. 'Negotiating between Children and Adult Design Values in Open Space Projects'. Design Studies 9 (2): 67-75. https://doi.org/10.1016/0142694X(88)90032-4.

Franzosi, Roberto P. 2004. 'Content Analysis'. In Handbook of Data Analysis, 548-65. 1 Oliver's Yard, 55 City Road, London England EC1Y 1SP United Kingdom: SAGE Publications, Ltd. https://doi.org/10.4135/9781848608184.n24.

Gallahue, David, and Frances Cleland-Donnelly. 2007. Developmental Physical Education for All Children. 4th ed. United States: Human Kinetics.

Gelisli, Yucel, and Elcin Yazici. 2015. 'A Study into Traditional Child Games Played in Konya Region in Terms of Development Fields of Children'. Procedia - Social and Behavioral Sciences $197 \quad$ (July): 1859-65. https://doi.org/10.1016/j.sbspro.2015.07.247.

Ginsburg, K. R. 2007. 'The Importance of Play in Promoting Healthy Child Development and Maintaining Strong Parent-Child Bonds'. PEDIATRICS $119 \quad$ (1): 182-91. https://doi.org/10.1542/peds.2006-2697.

Goodway, Jacqueline D., John C. Ozmun, and David L. Gallahue. 2019. Understanding Motor Development: Infants, Children, 
Adolescents, Adults. 8th ed. Burlington, Massachusetts, United States: Jones \& Bartlett Learning.

Harten, Nathan, Tim Olds, and Jim Dollman. 2008. 'The Effects of Gender, Motor Skills and Play Area on the Free Play Activities of 8-11 Year Old School Children'. Health \& Place $\quad 14 \quad$ (3): $\quad 386-93$. https://doi.org/10.1016/j.healthplace.2007.08. 005.

Hughes, Fergus P. 2009. Children, Play, and Development. 4th ed. Thousand Oaks, California, United States: SAGE Publications, Inc.

Karsten, L., and W. Van Vliet. 2006. 'Children in the City: Reclaiming the Street'. Children, Youth and Environments 16 (1): 151-67. https://www.researchgate.net/publication/254 897061_Children_in_the_city_Reclaiming_t he_street.

Klein, M. 1929. 'Personification in the Play of Children'. The International Journal of Psychoanalysis 10: 193-204. https://psycnet.apa.org/record/1930-00607001.

Kuczyński, Janusz. 1984. 'Play as Negation and Creation of the World'. Dialectics and Humanism 11 (1): 137-67.

Kurniati, Euis. 2016. Permainan Tradisional Dan Peranannya Dalam Mengembangkan Keterampilan Sosial Anak. Jakarta: Prenadamedia Group.

Kustianingrum, Dwi. 2010. 'Tatanan Spasial Permukiman Tak Terencana Kampung Babakan Ciamis Kota Bandung'. Jurnal Rekayasa 14 https://www.neliti.com/publications/218790/t atanan-spasial-permukiman-tak-terencanakampung-babakan-ciamis-kota-bandung.

Lafferty, Moira. 2005. 'Book Review: Developmental Physical Education for All Children, 4th Edn'. European Physical Education Review 11 (1): 108-9. https://doi.org/10.1177/1356336X05049827.

Liem, Yoseph, and Reginaldo Chistophori Lake. 2018. 'Pemaknaan Ruang Terbuka Publik Taman Nostalgia Kota Kupang'. ARTEKS : Jurnal Teknik Arsitektur 2 (2): 149-58. https://doi.org/10.30822/arteks.v2i1.48.

Mahagarmitha, Rilia Rigina. 2018. 'Community Participation in The Development of Kampung Warna-Warni Teluk Seribu In Balikpapan City'. ARTEKS: Jurnal Teknik
Arsitektur 3 (1): 57-70. https://doi.org/10.30822/arteks.v3i1.54.

Nur, Haerani. 2013. 'Membangun Karakter Anak Melalui Permainan Anak Tradisional'. Jurnal Pendidikan Karakter 3 (1): 87-94. https://journal.uny.ac.id/index.php/jpka/articl e/view/1290/1074.

Owens, Karen. 1992. The World of the Child. London, England: Pearson.

Papalia, Diane E., Sally Wendkos Olds, and Ruth Duskin Feldman. 2005. Human Development. 10th ed. New York City: McGraw-Hill Humanities Social.

Peskin, Joan, and V. Ardino. 2003. 'Representing the Mental World in Children's Social Behavior: Playing Hide-and-Seek and Keeping a Secret'. Social Development 12 (4): 496-512. http://hdl.handle.net/1807/65186.

Piaget, Jean. 2013a. Play, Dreams And Imitation In Childhood. Routledge. https://doi.org/10.4324/9781315009698.

- 2013b. The Construction Of Reality In The Child. https://doi.org/10.4324/9781315009650.

Piaget, Jean, and Margaret Cook. 1952. The Origins of Intelligence in Children. Madison, CT, United States: International Universities Press.

Purbadi, Yohanes Djarot, Achmad Djunaedi, and Sudaryono. 2019. 'The Kaenbaun Wisdom as a Conceptual Basis of the Spatial Design of Settlement Architecture of Dawanese in Kaenbaun Village'. ARTEKS : Jurnal Teknik $\begin{array}{llll}\text { Arsitektur } & 3 & \text { (2): } & \text { 215-38. }\end{array}$ https://doi.org/10.30822/arteks.v3i2.71.

Refranisa. 2019. 'The Settlement Pattern in Dusun Mantran Wetan of Magelang in the Frame of Javanese Culture'. ARTEKS : Jurnal Teknik Arsitektur 3 (2): 159-70. https://doi.org/10.30822/arteks.v3i2.67.

Riyadi, S. 2020. '11 Permainan Tradisional Anak Indonesia \& Cara Bermainnya'. KabarGames. 2020. https://www.kabargames.id/permainantradisional-indonesia/.

Rogers, Carolyn Odom. 1976. The Relationship Between the Organization of Play Space and Children's Behavior. United States: ERIC Clearinghouse.

Roopnarine, Jaipaul L. 2011. Cultural Variations in Beliefs about Play, Parent-Child Play, and Children's Play: Oxford, England: Oxford University

Press. 
https://doi.org/10.1093/oxfordhb/978019539 3002.013.0003.

Roscoe, Andrew. 2018. 'Adults Want Children to Play with "Traditional" Toys Such As Board Games and Science Kits, Study Finds'. Independent. 2018.

https://www.independent.co.uk/lifestyle/health-and-families/toys-childrentraditional-board-games-science-kitmicroscopes-parents-christmasa8635401.html.

Senda, Mitsuru. 1992. Design of Children's Play Environments. New York City: McGraw-Hill.

Senda, Mitsuru, Tsutomu Yata, Kouichi Asano, and Tetsuya Honda. 1998. 'Children's Play Spaces in Modern Japanese Juvenile Literature'. Journal of Architecture and Planning (Transactions of AIJ) 63 (510): $177-$ 83. https://doi.org/10.3130/aija.63.177_3.

Shinta, Dwi Kumala, Ibnu Syamsi, and Haryanto Haryanto. 2019. 'Traditional Game as a Media for Character Education Inclusion Elementary School'. In Proceedings of the International Conference on Special and Inclusive Education (ICSIE 2018). Paris, France: Atlantis Press. https://doi.org/10.2991/icsie18.2019.77.

Silaen, Febria. 2017. 'Permainan Tradisional Khas Indonesia'. Lokadata. 2017. https://lokadata.id/artikel/permainantradisional-khas-indonesia.

Solnit, Albert J. 1998. 'Beyond Play and Playfulness'. The Psychoanalytic Study of the
Child $\quad 53 \quad$ (1): $\quad 102-10$. https://doi.org/10.1080/00797308.1998.1182 2478.

Sunarya, Andi Rustandi. 2013. 'Pérépét Jengkol'. Blogna Andi Rustandi Sunarya. 2013. https://andirustandisunarya.wordpress.com/2 013/12/31/perepet-jengkol/.

Tranter, Paul J., and John W. Doyle. 1996. 'Reclaiming the Residential Street as Play Space'. International Journal of Play Therapy 4: 91-97. http://ecoplan.org/children/general/tranter.ht $\mathrm{m}$.

Waite, Sue, Sue Rogers, and Julie Evans. 2013. 'Freedom, Flow and Fairness: Exploring How Children Develop Socially at School through Outdoor Play'. Journal of Adventure Education \& Outdoor Learning 13 (3): 25576.

https://doi.org/10.1080/14729679.2013.7985 90.

Wonoseputro, Christine. 2007. 'Ruang Publik Sebagai Tempat Bermain Bagi Anak-Anak: Studi Kasus Pengembangan "The Urban Zoo" Bagi Kawasan Pecinan Di Singapura'. DIMENSI (Journal of Architecture and Built Environment) $\quad 35 \quad$ (1): 73-79. https://doi.org/10.9744/dimensi.35.1.73-79.

Yudiwinata, Hikmah Prisia. 2014. 'Permainan Tradisional Dalam Budaya Dan Perkembangan Anak'. Paradigma 2 (1): 1-5. https://jurnalmahasiswa.unesa.ac.id/index.ph p/paradigma/article/view/9088/8915. 
ARTEKS : Jurnal Teknik Arsitektur, Volume 5, Issue 3, December 2020

pISSN 2541-0598; eISSN 2541-1217 